https://helda.helsinki.fi

\title{
Properties of Atomic Layer Deposited Nanolaminates of Zirconium and Cobalt Oxides
}

\section{Seemen, Helina}

2018-07-28

Seemen , H, Rähn , M , Kalam , K, Sajavaara , T, Duenas , S , Castan , H , Link , J , Stern , R , Kukli , K \& Tamm , A 2018 , ' Properties of Atomic Layer Deposited Nanolaminates of Zirconium and Cobalt Oxides ' , ECS Journal of Solid State Science and Technology, vol. 7 , no. 8 , pp. P402-P409 . https://doi.org/10.1149/2.0191808jss

http://hdl.handle.net/10138/239084

https://doi.org/10.1149/2.0191808jss

cc_by

publishedVersion

Downloaded from Helda, University of Helsinki institutional repository.

This is an electronic reprint of the original article.

This reprint may differ from the original in pagination and typographic detail.

Please cite the original version. 


\title{
Properties of Atomic Layer Deposited Nanolaminates of Zirconium and Cobalt Oxides
}

\author{
and Aile Tamm (i) 1 \\ ${ }^{1}$ Institute of Physics, University of Tartu, 50411 Tartu, Estonia \\ ${ }^{2}$ Department of Physics, University of Jyväskylä, 40500 Jyväskylä, Finland \\ ${ }^{3}$ Department of Electronics, University of Valladolid, 47011 Valladolid, Spain \\ ${ }^{4}$ National Institute of Chemical Physics and Biophysics, 12618 Tallinn, Estonia \\ ${ }^{5}$ Department of Chemistry, University of Helsinki, FI-00014 Helsinki, Finland
}

Helina Seemen, ${ }^{1, z}$ Mihkel Rähn, ${ }^{1}$ Kristjan Kalam, ${ }^{1}{ }^{1}$ Timo Sajavaara, ${ }^{2}{ }^{2}$ Salvador Dueñas, $\oplus^{3}$ Helena Castán, $\oplus^{3}$ Joosep Link, ${ }^{4}$ Raivo Stern, ${ }^{4}$ Kaupo Kukli, $₫ 1,5$

\begin{abstract}
Five-layer crystalline thin film structures were formed, consisting of $\mathrm{ZrO}_{2}$ and $\mathrm{Co}_{3} \mathrm{O}_{4}$ alternately grown on $\mathrm{Si}(100)$ substrates by atomic layer deposition at $300^{\circ} \mathrm{C}$ using $\mathrm{ZrCl}_{4}$ and $\mathrm{Co}(\mathrm{acac})_{3}$ as the metal precursors and ozone as the oxygen precursor. The performance of the laminate films was dependent on the relative content of constituent oxide layers. The magnetization in these films was nonlinear, saturative, and with very weak coercive fields. Electrical measurements revealed the formation of significant polarization versus external field loops and implied some tendency toward memristive behavior.

(C) The Author(s) 2018. Published by ECS. This is an open access article distributed under the terms of the Creative Commons Attribution 4.0 License (CC BY, http://creativecommons.org/licenses/by/4.0/), which permits unrestricted reuse of the work in any medium, provided the original work is properly cited. [DOI: $10.1149 / 2.0191808 \mathrm{jss}$ ]

(cc) BY
\end{abstract}

Manuscript submitted June 11, 2018; revised manuscript received July 19, 2018. Published July 28, 2018.

$\mathrm{Co}_{3} \mathrm{O}_{4}$ and $\mathrm{ZrO}_{2}$ thin films and their nanolaminates are of interest as functional thin films possessing advanced electronic, optical, magnetic and mechanical properties, making these materials attractive for several applications.

$\mathrm{ZrO}_{2}$ can be used in gas sensors, ${ }^{1,2}$ catalytic supports, ${ }^{3,4}$ thermal barrier coatings, ${ }^{5,6}$ buffer layers for superconductors ${ }^{7,8}$ and as dielectric material in dynamic random access memory (DRAM) ${ }^{9-13}$ and resistive random access memory (RRAM) devices. ${ }^{14,15}$

$\mathrm{Co}_{3} \mathrm{O}_{4}$ has been investigated as a gas sensor, ${ }^{16,17}$ catalyst, ${ }^{18,19}$ anode material for lithium-ion batteries, ${ }^{20}$ supercapacitor electrode, ${ }^{21}$ superhydrophobic coating, ${ }^{22,23}$ and magnetic semiconductor. ${ }^{24} \mathrm{Co}_{3} \mathrm{O}_{4}$ has also demonstrated resistive switching properties, which are important regarding its potential applications in RRAM devices. ${ }^{25,26}$

$\mathrm{Co}_{3} \mathrm{O}_{4}$ and $\mathrm{ZrO}_{2}$ oxides may be grown using different physical and chemical techniques, such as solution spray pyrolysis, ${ }^{27-29}$ chemical vapor deposition, ${ }^{30-33}$ pulsed laser deposition, ${ }^{34,35}$ solgel, ${ }^{36,37}$ electron-beam evaporation, ${ }^{38,39}$ or, atomic layer deposition (ALD).$^{40-46}$ Herewith, ALD may be regarded as the ultimate method providing the most precise thickness control over large substrate areas.

$\mathrm{ZrO}_{2}$ has been used in nanolaminates as one alternating component together with, e.g., $\mathrm{Al}_{2} \mathrm{O}_{3},{ }^{47-50} \mathrm{SiO}_{2},{ }^{51} \mathrm{Ta}_{2} \mathrm{O}_{5},{ }^{52,53} \mathrm{HfO}_{2},{ }^{53,54}$ $\mathrm{Er}_{2} \mathrm{O}_{3},{ }^{55} \mathrm{Gd}_{2} \mathrm{O}_{3},{ }^{56}$ and $\mathrm{Y}_{2} \mathrm{O}_{3} .{ }^{57}$ Studies on nanolaminates or multilayered structures containing $\mathrm{Co}_{3} \mathrm{O}_{4}$ as one of the constituents ${ }^{58,59}$ as well as ALD-grown nanolaminates containing both $\mathrm{Co}_{3} \mathrm{O}_{4}$ and $\mathrm{ZrO}_{2}{ }^{59}$ have so far been quite scarce. In the earlier study devoted to $\mathrm{ZrO}_{2}-\mathrm{Co}_{3} \mathrm{O}_{4}$ nanocomposites grown by ALD using the same chemistry based on cobalt acetylacetonate, zirconium tetrachloride and ozone, ${ }^{59}$ the deposition process for cobalt oxide was investigated and established, determining suitable evaporation temperature for $\mathrm{Co}(\mathrm{acac})_{3}$ precursor, as well as by recording linear relationship between growing mass and the amount of deposition cycles. Using the suitable deposition parameters, ALD growth of $\mathrm{ZrO}_{2} / \mathrm{Co}_{3} \mathrm{O}_{4}$ double layers was demonstrated, together with their performance as dielectric and magnetic materials.

In connection with the demand for materials, which could be applied in novel memories because of their advanced magnetic and electric properties, this study was devoted to the description of $\mathrm{ZrO}_{2}$ $\mathrm{Co}_{3} \mathrm{O}_{4}$ nanolaminates, grown by $\mathrm{ALD}$ using $\mathrm{ZrCl}_{4}$ and $\mathrm{Co}(\mathrm{acac})_{3}$ as the metal precursors and ozone as the oxygen precursor. Elemental and phase composition, thickness, surface morphology and the polarization characteristics of the samples in the presence of an external magnetic or electric field were determined. In addition, the resistive switching and other electrical characteristics of $\mathrm{ZrO}_{2}-\mathrm{Co}_{3} \mathrm{O}_{4}$ nanolaminates were studied to evaluate whether such films can imply a tendency toward memristive behavior.

\section{Experimental}

The film growth experiments were carried out in a flow-type inhouse built hot-wall ALD reactor ${ }^{60}$ at $300 \pm 2^{\circ} \mathrm{C}$ using $\mathrm{ZrCl}_{4}(99.99 \%$, Sigma Aldrich) and Co(acac) 3 (99.9\%, Volatec Ltd.) [acac $=\operatorname{tris}(2,4-$ pentanedionato)] as the metal precursors, $\mathrm{O}_{3}$ as the oxygen precursor and $\mathrm{N}_{2}(99.999 \%, \mathrm{AGA})$ as the carrier and purge gas. The $\mathrm{ZrCl}_{4}$ and $\mathrm{Co}(\mathrm{acac})_{3}$ were evaporated at $160 \pm 2{ }^{\circ} \mathrm{C}$ and $120 \pm 2^{\circ} \mathrm{C}$, respectively, from open boats inside the reactor and transported to the substrates by the carrier gas flow. $\mathrm{O}_{3}$ was generated from $\mathrm{O}_{2}(99.999 \%$, AGA, Linde Group) in a BMT Messtechnik $802 \mathrm{~N}$ ozone generator. The $\mathrm{O}_{3}$ concentration output of the generator measured with BMT Masstechnik 964 analyzer was $\sim 262 \mathrm{~g} / \mathrm{m}^{3}$ at the normal pressure. During the deposition, the chamber pressure varied in the range of 205-260 Pa. In all cases, a single ALD cycle was started with a metal precursor pulse and continued with a purge of the reaction zone with the pure carrier gas, oxygen precursor pulse and another purge. The precursor pulse durations and purge lengths in the case of $\mathrm{ZrO}_{2}$ reference films were 5-5-5-5 $\mathrm{s}$ and in the case of $\mathrm{Co}_{3} \mathrm{O}_{4}$ reference films were 5-3-5-5 s, denoting the sequence of metal precursor pulse $-\mathrm{N}_{2}$ purge $-\mathrm{O}_{3}$ pulse $-\mathrm{N}_{2}$ purge. The number of cycles for both reference films was 250 . In the case of the nanolaminates, the precursor pulse durations and purge lengths were 5-5-5-5 $\mathrm{s}$ and 7-5-5-5 $\mathrm{s}$ for $\mathrm{ZrO}_{2}$ and $\mathrm{Co}_{3} \mathrm{O}_{4}$, respectively. The $\mathrm{Co}(\mathrm{acac})_{3}$ pulse time was prolonged by 2 seconds during the deposition of the layered structures, in order to ensure more uniform adsorption of precursor molecules and deposition of the oxide more evenly along the gas flow. $\mathrm{ZrO}_{2}-\mathrm{Co}_{3} \mathrm{O}_{4}$ nanolaminates consisting of 5 alternating layers starting with $\mathrm{ZrO}_{2}$ layer and ending, again, with $\mathrm{ZrO}_{2}$ as the topmost layer were grown using the total sequence of $2 \times$ $\left[\left(100 \times\left(\mathrm{ZrCl}_{4} / \mathrm{O}_{3}\right)+200 \times\left(\mathrm{Co}(\mathrm{acac})_{3} / \mathrm{O}_{3}\right)\right]+100 \times\left(\mathrm{ZrCl}_{4} / \mathrm{O}_{3}\right)\right.$ cycles. The abbreviation $2 \times\left(\mathrm{ZrO}_{2}+\mathrm{Co}_{3} \mathrm{O}_{4}\right)+\mathrm{ZrO}_{2}$ will be used throughout the article for indicating that nanolaminate. The nanolaminates starting with $\mathrm{Co}_{3} \mathrm{O}_{4}$ layer and ending also with $\mathrm{Co}_{3} \mathrm{O}_{4}$ as the topmost layer were grown using the total sequence of $2 \times[(200 \times$ $\left.\left(\mathrm{Co}(\mathrm{acac})_{3} / \mathrm{O}_{3}\right)+100 \times\left(\mathrm{ZrCl}_{4} / \mathrm{O}_{3}\right)\right]+200 \times\left(\mathrm{Co}(\mathrm{acac})_{3} / \mathrm{O}_{3}\right)$ cycles. This particular laminate will further be denoted as $2 \times\left(\mathrm{Co}_{3} \mathrm{O}_{4}+\right.$ $\left.\mathrm{ZrO}_{2}\right)+\mathrm{Co}_{3} \mathrm{O}_{4}$, throughout the paper. Pieces of undoped $\mathrm{Si}(100)$ wafers as well as highly-doped $\mathrm{Si}$ covered by TiN layer were exploited as substrates. TiN layer was deposited using $\mathrm{TiCl}_{4} / \mathrm{NH}_{3}$ process in an ASM A412 Large Batch $300 \mathrm{~mm}$ reactor at Fraunhofer IPMS-CNT. 


\begin{tabular}{|c|c|c|c|c|c|c|}
\hline & $\mathrm{Co}_{3} \mathrm{O}_{4}$ & $\mathrm{ZrO}_{2}$ & \multicolumn{2}{|c|}{$\begin{array}{c}2 \times\left(\mathrm{Co}_{3} \mathrm{O}_{4}+\mathrm{ZrO}_{2}\right) \\
+\mathrm{Co}_{3} \mathrm{O}_{4}\end{array}$} & \multicolumn{2}{|c|}{$\begin{array}{c}2 \times\left(\mathrm{ZrO}_{2}+\mathrm{Co}_{3} \mathrm{O}_{4}\right) \\
+\mathrm{ZrO}_{2}\end{array}$} \\
\hline Total thickness, nm (XRF) & $15.6 \pm 1.0$ & $32.9 \pm 1.0$ & \multicolumn{2}{|c|}{$64.0 \pm 1.0$} & \multicolumn{2}{|c|}{$59.7 \pm 1.0$} \\
\hline Total thickness, nm (ellipsometry) & $17.4 \pm 1.0$ & $29.9 \pm 1.0$ & & & & \\
\hline No. of ALD cycles for 1 layer & 250 & 250 & $\begin{array}{c}\mathrm{Co}_{3} \mathrm{O}_{4} \\
200\end{array}$ & $\begin{array}{c}\mathrm{ZrO}_{2} \\
100\end{array}$ & $\begin{array}{c}\mathrm{Co}_{3} \mathrm{O}_{4} \\
200\end{array}$ & $\begin{array}{c}\mathrm{ZrO}_{2} \\
100\end{array}$ \\
\hline Total thickness of specified oxide, $\mathrm{nm}$ (XRF) & & & $41.9 \pm 1.0$ & $22.1 \pm 1.0$ & $25.6 \pm 1.0$ & $34.1 \pm 1.0$ \\
\hline Estimated thickness of a single oxide layer, nm (XRF) & & & $14.0 \pm 2.0$ & $11.1 \pm 2.0$ & $12.8 \pm 2.0$ & $11.4 \pm 2.0$ \\
\hline Growth rate, $\mathrm{nm} /$ cycle & 0.06 & 0.13 & 0.21 & 0.22 & 0.13 & 0.34 \\
\hline
\end{tabular}

In the case of undoped $\mathrm{Si}(100)$, the native $\mathrm{SiO}_{2}$ was removed using HF. The conducting substrates were based on (100)-oriented silicon with resistivity in the range of $0.014-0.020 \Omega \cdot \mathrm{cm}$, i.e., boron-doped to concentrations up to $5 \times 10^{18}-1 \times 10^{19} / \mathrm{cm}^{3}$, and coated with $10 \mathrm{~nm}$ thick chemical vapor deposited titanium nitride layer.

The mass thickness and elemental composition of the films were measured by X-ray fluorescence (XRF) spectroscopy method using ZSX400 (Rigaku) spectrometer. Grazing incidence X-ray diffraction (GIXRD) was applied for structural studies and all XRD studies were carried out with Smartlab (Rigaku) X-ray analyzer using $\mathrm{CuK} \alpha$ radiation. Thicknesses of the $\mathrm{ZrO}_{2}$ and $\mathrm{Co}_{3} \mathrm{O}_{4}$ reference films were determined using GES5E (Sopra-Semilab) spectroscopic ellipsometer. The composition profile of selected films, including the detection and determination of the content of light residues such as hydrogen, carbon and nitrogen, was evaluated by time-of-flight elastic recoil detection analysis (ToF-ERDA). ToF-ERDA was carried out using $11.915 \mathrm{MeV}^{63} \mathrm{Cu}^{7+}$ ion beam. The geometry used for measurements was $10^{\circ}+31^{\circ}$

The morphology of nanolaminates on Si substrate was investigated by scanning electron microscopy (SEM) using FEI Helios Nanolab 600 DualBeam microscope equipped with focused ion beam (FIB) module and Omniprobe model 100.7 in-situ nanomanipulator. Ga FIB was employed for the preparation of the lamellae of the $\mathrm{ZrO}_{2}-\mathrm{Co}_{3} \mathrm{O}_{4}$ nanolaminates, being used for milling, thinning and polishing. The nanomanipulator was used for transportation of the lamellae to the lift-out type grid and Pt deposition was used for lamellae attachment steps. Before the start of the milling process, small $(\sim 20 \times 1 \mu \mathrm{m})$ and thin $(\sim 1 \mu \mathrm{m})$ rectangular shaped $\mathrm{C}$ and Pt layers were deposited on top of the object using electron beam (for the first $\mathrm{C}$ and $\mathrm{Pt}$ layers) and $\mathrm{Ga}$ ion beam (the last Pt layer) to protect the area of interest during the lamella creation process. For that, the gas compound, which was naphthalene $\left[\mathrm{C}_{10} \mathrm{H}_{8}\right]$ for $\mathrm{C}$ deposition and methyl cyclopentadienyl trimethyl platinum $\left[\left(\mathrm{CH}_{3}\right)_{3} \mathrm{Pt}\left(\mathrm{CpCH}_{3}\right)\right]$ for $\mathrm{Pt}$ deposition, was exposed onto the target specimen, using the gas injection nozzle, and adsorbed on specimen's surface. This was followed by bombardment of focused beam on the adsorbed molecules within predefined patterns. After that routine milling process, lamellae transportation and attachment to the lift-out type TEM grid, final thinning and polishing process were completed. Lamella creation is one necessary preparation step to change a thin film object into a suitable form for transmission electron microscopy (TEM) studies. This lamella stores information about the cross-sectional structure and composition of the object.

Scanning transmission electron microscopy (STEM) studies for the characterization of the cross-sections of the nanolaminate structures were carried out using FEI Titan Themis 200 instrument with a field emission gun operated at $200 \mathrm{kV}$. The device was equipped with a probe $\mathrm{C}_{\mathrm{s}}$ corrector and a Bruker SuperX SDD Energy-dispersive $\mathrm{X}$-ray spectroscopy (EDX) system. The EDX system was used for the composition profiling of the $\mathrm{ZrO}_{2}-\mathrm{Co}_{3} \mathrm{O}_{4}$ nanolaminates.

Selected films were subjected to magnetic measurements. The measurements were performed using the P525 Vibrating Sample Magnetometer (VSM) option of the Physical Property Measurement System (PPMS) 14T (Quantum Design). Rectangular samples with the area of ca. $14.4 \pm 0.7 \mathrm{~mm}^{2}$ were fixed with GE 7031 vanish to the commercial quartz sample holders (Quantum Design). Hysteresis measurements were carried out at room temperature $(300 \mathrm{~K})$ by scanning the magnetic fields from -5000 to +5000 Oe (from -397.9 to $397.9 \mathrm{kA} / \mathrm{m}$ ) parallel to the film surface. The diamagnetic signal arising from the silicon substrate was subtracted from the general magnetization curve for all the samples in which the ferromagnetic like response was detected.

In order to carry out the electrical measurements, metal-insulatormetal (MIM) structures were prepared on conducting substrates. Top electrodes with area of $0.204 \mathrm{~mm}^{2}$ were formed by electron beam evaporation of $50 \mathrm{~nm}$ thick Pt layers directly contacting $\mathrm{ZrO}_{2}$ $\mathrm{Co}_{3} \mathrm{O}_{4}$ nanolaminates through a shadow mask. Capacitance-voltage $(\mathrm{C}-\mathrm{V})$ and current-voltage (I-V) measurements were carried out in a light-proof and electrically shielded box. Samples were electrically characterized in both d.c. and a.c. regimes using a Keithley 4200SCS semiconductor analyzer. The standard Sawyer-Tower experiment was carried out by using an Agilent DXO-X 3104 digital oscilloscope with a built-in wave generator. This experiment comprised applying a periodic triangular-shaped stimulus and recording the voltage loops data from the oscilloscope. Charge values were obtained from the sensed voltage across a stated capacitance.

\section{Results and Discussion}

Film growth, formation, structure and morphology.-On planar $\mathrm{Si}(100)$ substrates, the $\mathrm{Co}_{3} \mathrm{O}_{4}$ and $\mathrm{ZrO}_{2}$ reference films were grown to the thicknesses of $15.0 \pm 1.0$ and $32.0 \pm 1.0 \mathrm{~nm}$ after 250 growth cycles, respectively, according to the XRR measurements (Table I). Thus, the average growth rates of constituent oxides were 0.06 and $0.13 \mathrm{~nm} /$ cycle for $\mathrm{Co}_{3} \mathrm{O}_{4}$ and $\mathrm{ZrO}_{2}$ films, respectively. Reactor conditions, in particular temperature, reactor volume, but also cycle time and pressure parameters may somewhat affect the film growth rate. In an earlier study on ALD of $\mathrm{Co}(\mathrm{acac})_{3}$ and $\mathrm{O}_{3}$, the growth rate at $300^{\circ} \mathrm{C}$ was $0.03 \mathrm{~nm} /$ cycle. ${ }^{61} \mathrm{In}$ another study devoted to ALD of $\mathrm{ZrO}_{2}$ from $\mathrm{ZrCl}_{4}$ and $\mathrm{O}_{3}$, the growth rate at $300^{\circ} \mathrm{C}$ was $0.07 \mathrm{~nm} /$ cycle. $^{46}$ Both growth rates are smaller than those calculated in this study. As the reactors were different in both cases, the differences in the growth rates might be caused by different reactor chamber pressures and the concentrations of precursor in the carrier gas.

In the case of the nanolaminates, the estimated thickness of a single oxide layer (Table I) is the total measured thickness of the particular oxide in the film divided by the number of these oxide layers. Possible variations in the thicknesses of single oxide layers were not taken into account at this calculation. The growth rate of the metal oxide may be influenced by the substrate material, that is, the metal oxide might grow to the top of the substrate material with different rate compared to the growth on the top of another oxide layer.

As the precursors contained chlorine and carbon, the presence of these two elements as residual impurities in the deposited films is an expected result. Due to the small thickness of the single layers, the impurity contents with ToF-ERDA could only be integrated over the whole nanolaminate. Elemental depth profiles confirm rather low concentrations for impurities $-\mathrm{C}, \mathrm{Cl}$ and $\mathrm{H}$ (Fig. 1). The $\mathrm{C}, \mathrm{Cl}$ and $\mathrm{H}$ contents for $2 \times\left(\mathrm{Co}_{3} \mathrm{O}_{4}+\mathrm{ZrO}_{2}\right)+\mathrm{Co}_{3} \mathrm{O}_{4}$ nanolaminate were $0.5 \pm 0.1$ at. $\%, 0.12 \pm 0.02$ at. $\%, 1.4 \pm 0.2$ at. $\%$, respectively. And in the case of $2 \times\left(\mathrm{ZrO}_{2}+\mathrm{Co}_{3} \mathrm{O}_{4}\right)+\mathrm{ZrO}_{2}$ nanolaminate, the $\mathrm{C}, \mathrm{Cl}$ and $\mathrm{H}$ contents were $0.4 \pm 0.1$ at. $\%, 0.7 \pm 0.1$ at. $\%, 1.0 \pm 0.2$ at.\%. Both 

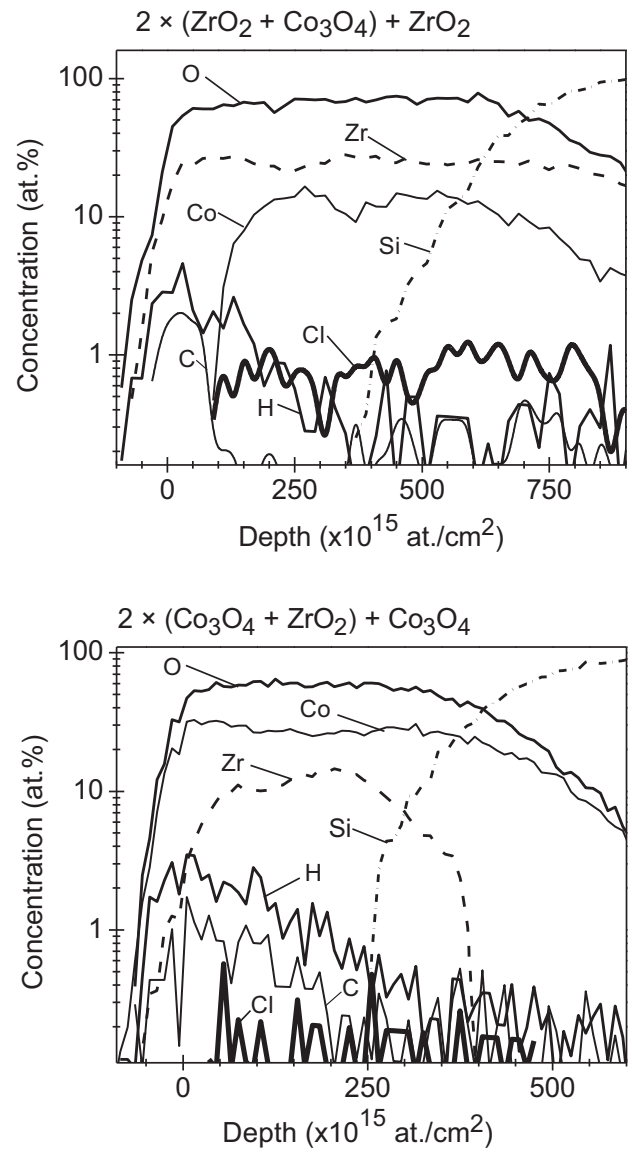

Figure 1. Elemental depth profiles determined by ToF-ERDA for the $2 \times\left(\mathrm{ZrO}_{2}+\mathrm{Co}_{3} \mathrm{O}_{4}\right)+\mathrm{ZrO}_{2}$ (upper panel) and $2 \times\left(\mathrm{Co}_{3} \mathrm{O}_{4}+\mathrm{ZrO}_{2}\right)+$ $\mathrm{Co}_{3} \mathrm{O}_{4}$ (lower panel) nanolaminates in the as-deposited state. The title above the graph indicates the type of nanolaminate.

$\mathrm{H}$ and $\mathrm{C}$ are concentrated in the first oxide layer or surface. Both $\mathrm{H}$ and $\mathrm{C}$ concentrations drop drastically deeper in the film stack.

Scanning electron microscope images demonstrated that the surfaces in the case of all four thin film structures (Fig. 2) were quite uniformly covered by grain-like features, which may easily be connected to crystallization, and also indicate that the deposition temperature of $300^{\circ} \mathrm{C}$ was high enough to cause crystallization in both $\mathrm{Co}_{3} \mathrm{O}_{4}$ and $\mathrm{ZrO}_{2}$ thin films. The similarity between those thin film multilayer structures that had the same type of oxide as the topmost layer implies that in the case of nanolaminates, the layers are probably not mixed and the upmost layer is indeed the oxide layer that was defined in the ALD experiment and displayed on the explanatory schematics (Fig. 2). One can also notice that the charging effect has taken place in the case of the $\mathrm{ZrO}_{2}$ layers, which can be seen by the bright white areas. This effect is more characteristic of the non-conductive (insulating) materials. In Ramesh et al. ${ }^{62}$ it has been stated that, in order to be ferroelectric, a material must be insulating (otherwise the mobile charges would screen out the electric polarization).

GIXRD (Fig. 3) confirmed that the reference thin films and $\mathrm{ZrO}_{2}$ $\mathrm{Co}_{3} \mathrm{O}_{4}$ nanolaminates were all crystallized already in the as-deposited state. The diffractogram of the reference $\mathrm{ZrO}_{2}$ thin film (Fig. 3) contained five reflections $111,200,220,311$ and 222 at $30.5^{\circ}, 35.2^{\circ}$, $50.6^{\circ}, 60.3^{\circ}$ and $63.2^{\circ}$, respectively, attributable to cubic $\mathrm{ZrO}_{2}$ phase (PDF card 00-027-0997). Reflections 111,111 and 131 at $28.2^{\circ}, 31.5^{\circ}$, $59.8^{\circ}$, respectively, could be attributed to the monoclinic $\mathrm{ZrO}_{2}$ phase (PDF card 00-037-1484). In an earlier study, ${ }^{46}$ the formation of both cubic and monoclinic $\mathrm{ZrO}_{2}$ phases in the thin films deposited at the same temperature and from the same precursors has been described.
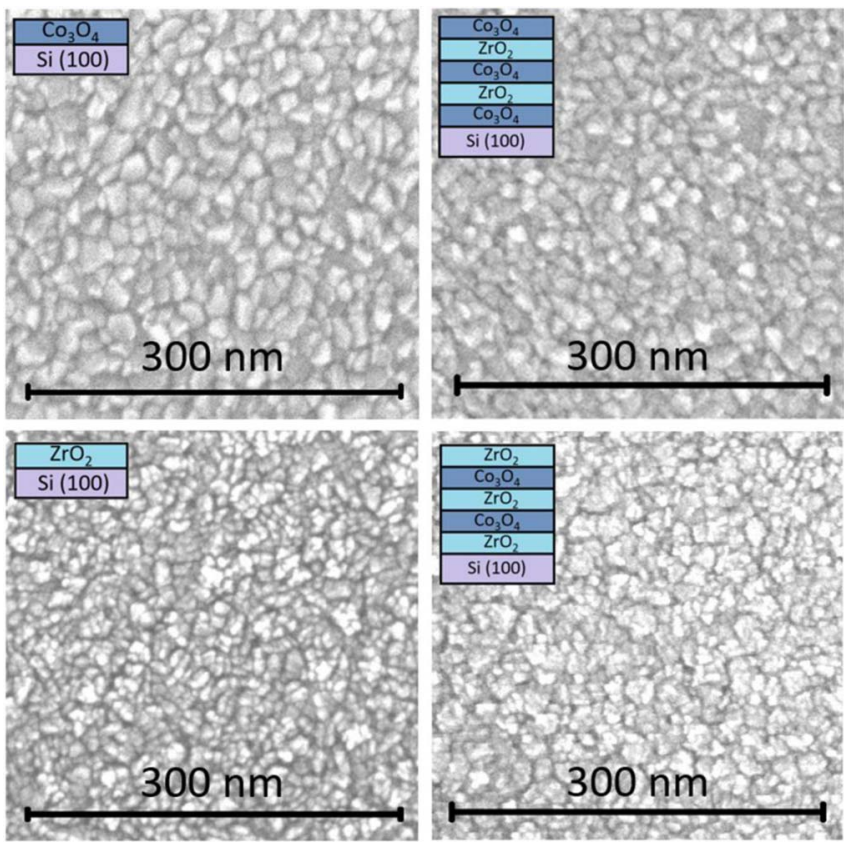

Figure 2. The bird-eye view of the scanning electron microscope images of $\mathrm{ZrO}_{2}$ and $\mathrm{Co}_{3} \mathrm{O}_{4}$ thin films and $\mathrm{ZrO}_{2}-\mathrm{Co}_{3} \mathrm{O}_{4}$ nanolaminates as-deposited with explanatory schematics indicating the order and the amount of layers deposited.

In the diffractogram of the reference $\mathrm{Co}_{3} \mathrm{O}_{4}$ thin film, six peaks attributable to the $220,311,400,422,511$ ja 440 reflexes from the cubic phase were detected at $31.3^{\circ}, 36.9^{\circ}, 44.8^{\circ}, 55.7^{\circ}, 59.4^{\circ}$ and $65.2^{\circ}$ (PDF card 00-042-1467). In an earlier study by Klepper et al. ${ }^{63}$ on $\mathrm{Co}_{3} \mathrm{O}_{4}$, atomic layer deposited at $283^{\circ} \mathrm{C}$, the cubic phase has also been detected. While comparing the diffractograms of the nanolaminates one could notice that in the case of the nanolaminate, that had the $\mathrm{ZrO}_{2}$ as the top-most layer, the peak intensities were noticeably higher and therefore the interlayers must be more ordered compared to the nanolaminate that had $\mathrm{Co}_{3} \mathrm{O}_{4}$ as the top-most layer. Probably the dominant phase is the cubic $\mathrm{ZrO}_{2}$ polymorph, although the tetragonal and/or orthorhombic $\mathrm{ZrO}_{2}$ in the phase composition cannot be completely ruled out.

In STEM images made of both types of nanolaminates (Fig. 4, the leftmost-panel of (a) and (b)), five distinct metal oxide layers grown sequentially on the $\mathrm{Si}$ substrate can be seen. Cross-sectional EDX composition profiling of the $\mathrm{ZrO}_{2}-\mathrm{Co}_{3} \mathrm{O}_{4}$ nanolaminates in the asdeposited state (Fig. 4, 4 small panels of (a) and (b) on the right)

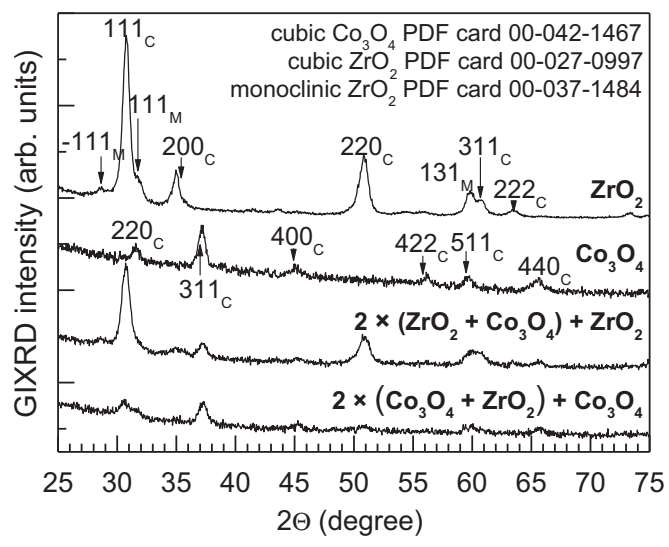

Figure 3. X-ray diffraction patterns from the $\mathrm{Co}_{3} \mathrm{O}_{4}$ and $\mathrm{ZrO}_{2}$ thin films and $\mathrm{ZrO}_{2}-\mathrm{Co}_{3} \mathrm{O}_{4}$ nanolaminates, in the as-deposited state. Miller indexes assigned after crystallization are indicated with " $\mathrm{C}$ " for cubic and " $\mathrm{M}$ " for monoclinic phase. 

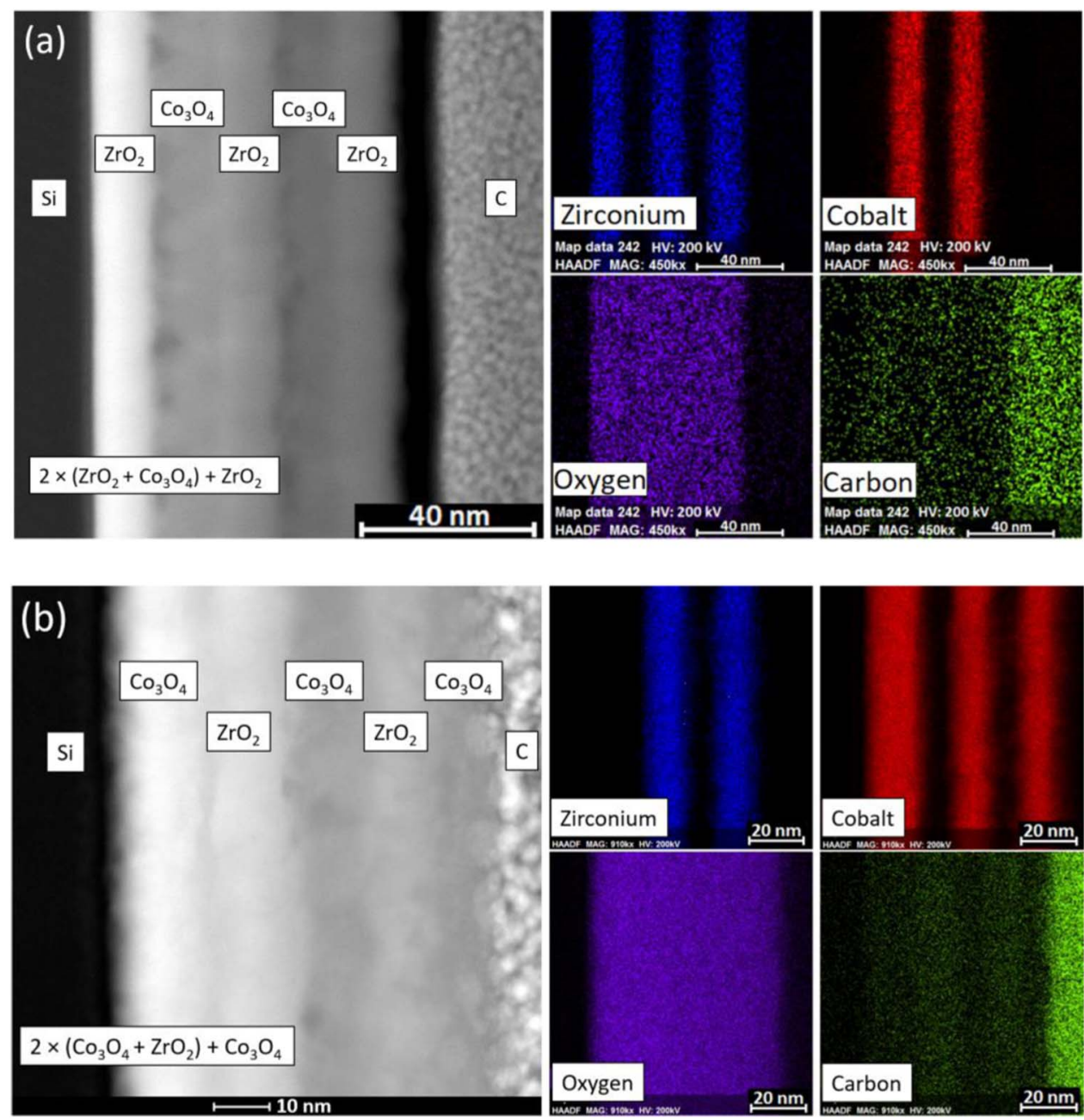

Figure 4. Cross-sectional EDX composition profiling of the (a) $2 \times\left(\mathrm{ZrO}_{2}+\mathrm{Co}_{3} \mathrm{O}_{4}\right)+\mathrm{ZrO}_{2}$ nanolaminate and (b) $2 \times\left(\mathrm{Co}_{3} \mathrm{O}_{4}+\mathrm{ZrO}_{2}\right)+\mathrm{Co}_{3} \mathrm{O}_{4}$ nanolaminate in the as-deposited state. STEM images of the site of interest are displayed on the left panels. The elements detected are indicated by labels and colors displayed on the right panels. Carbon on top of the layers originates from lamellae creation process where it acted as a protective layer.

showed that in the case of the $2 \times\left(\mathrm{Co}_{3} \mathrm{O}_{4}+\mathrm{ZrO}_{2}\right)+\mathrm{Co}_{3} \mathrm{O}_{4}$ nanolaminate, three chemically distinct cobalt-containing and two zirconium-containing layers alternated as expected. In the case of $2 \times$ $\left(\mathrm{ZrO}_{2}+\mathrm{Co}_{3} \mathrm{O}_{4}\right)+\mathrm{ZrO}_{2}$ one can see three alternating zirconium and two cobalt-containing layers. Therefore, the structure of the nanolaminates corresponded to the schematics described in the experimental section. In the case of both nanolaminates, the oxygen signal was detected relatively homogeneously across all five metal oxide layers, as expected. One can also see that the thicknesses of the oxide layers are quite similar indeed, except that in the case of the first layer of $2 \times\left(\mathrm{Co}_{3} \mathrm{O}_{4}+\mathrm{ZrO}_{2}\right)+\mathrm{Co}_{3} \mathrm{O}_{4}$ nanolaminate, where the cobalt oxide occurred slightly thicker compared to the other layers.

Comparison of STEM images and EDX composition profiling made of both types of nanolaminates (Fig. 5) revealed that slight mixing of oxide layers at the interfaces between two oxides has occurred in both cases. Nevertheless, the appearance of distinguishable lattice planes is indicative of ordered structure. In the case of the $2 \times\left(\mathrm{ZrO}_{2}+\right.$ $\left.\mathrm{Co}_{3} \mathrm{O}_{4}\right)+\mathrm{ZrO}_{2}$ nanolaminate the STEM image taken from one other location (Fig. 6) revealed probably a local phenomenon in the form of apparently round features. An apparently similar phenomenon has earlier been observed in the case of atomic layer deposited $\mathrm{Ho}_{2} \mathrm{O}_{3}$ $\mathrm{TiO}_{2}$ nanolaminates ${ }^{64}$ where $\mathrm{Ho}_{2} \mathrm{O}_{3}$ and $\mathrm{TiO}_{2}$ layers were mixed after annealing and the nanolaminate structure was destroyed. If these features were hollow, then the appearance of such regions could be associated with the Kirkendall effect that can arise when two distinct materials are placed in contact to each other and their interdiffusion occurs by a vacancy mechanism. In the context of the present work, however, Kirkendall effect should be considered with caution and this phenomenon therefore would need further investigation. In our study, these round features are likely not voids due to the appearance of distinguishable lattice planes within those round features.

Magnetic and electrical behavior.-In-plane magnetic measurements were performed for as-deposited $\mathrm{ZrO}_{2}-\mathrm{Co}_{3} \mathrm{O}_{4}$ nanolaminates and reference $\mathrm{ZrO}_{2}$ and $\mathrm{Co}_{3} \mathrm{O}_{4}$ thin films. The structures demonstrated ferromagnetic-like behavior at room temperature with saturation magnetization (Fig. 7) and could therefore be described as rather soft ferromagnetics. In the $\boldsymbol{M}-\boldsymbol{H}$ curves the saturation magnetization values for the $\mathrm{ZrO}_{2}$ and $\mathrm{Co}_{3} \mathrm{O}_{4}$ were $3.7 \times 10^{-6} \mathrm{emu}$ and $3.5 \times 10^{-6} \mathrm{emu}$ at $300 \mathrm{~K}$, respectively. One can also notice that the $2 \times\left(\mathrm{ZrO}_{2}+\right.$ $\left.\mathrm{Co}_{3} \mathrm{O}_{4}\right)+\mathrm{ZrO}_{2}$ nanolaminate showed several times higher saturation magnetization $\left(1.7 \times 10^{-5} \mathrm{emu}\right)$ compared to the other samples. The coercivity values of films were low, ranging from around 24 to $60 \mathrm{Oe}$ ( 1.9 to $4.8 \mathrm{kA} / \mathrm{m}$ ), evaluated from their very narrow hysteresis loops.

At first, it might be a bit surprising to see that the nanolaminate that had three layers of $\mathrm{ZrO}_{2}$ and two layers of $\mathrm{Co}_{3} \mathrm{O}_{4}$ possessed that much better magnetic polarization compared to the laminate that had one more $\mathrm{Co}_{3} \mathrm{O}_{4}$ layer and one less $\mathrm{ZrO}_{2}$ layer. On the other hand, the magnetic behavior of $\mathrm{ZrO}_{2}$ thin films and nanoparticles has been reported before, ${ }^{65-68}$ and the magnetism was largely attributed to the formation and presence of oxygen deficient metastable zirconia phases. In the present study, it was confirmed, that the solid structures 


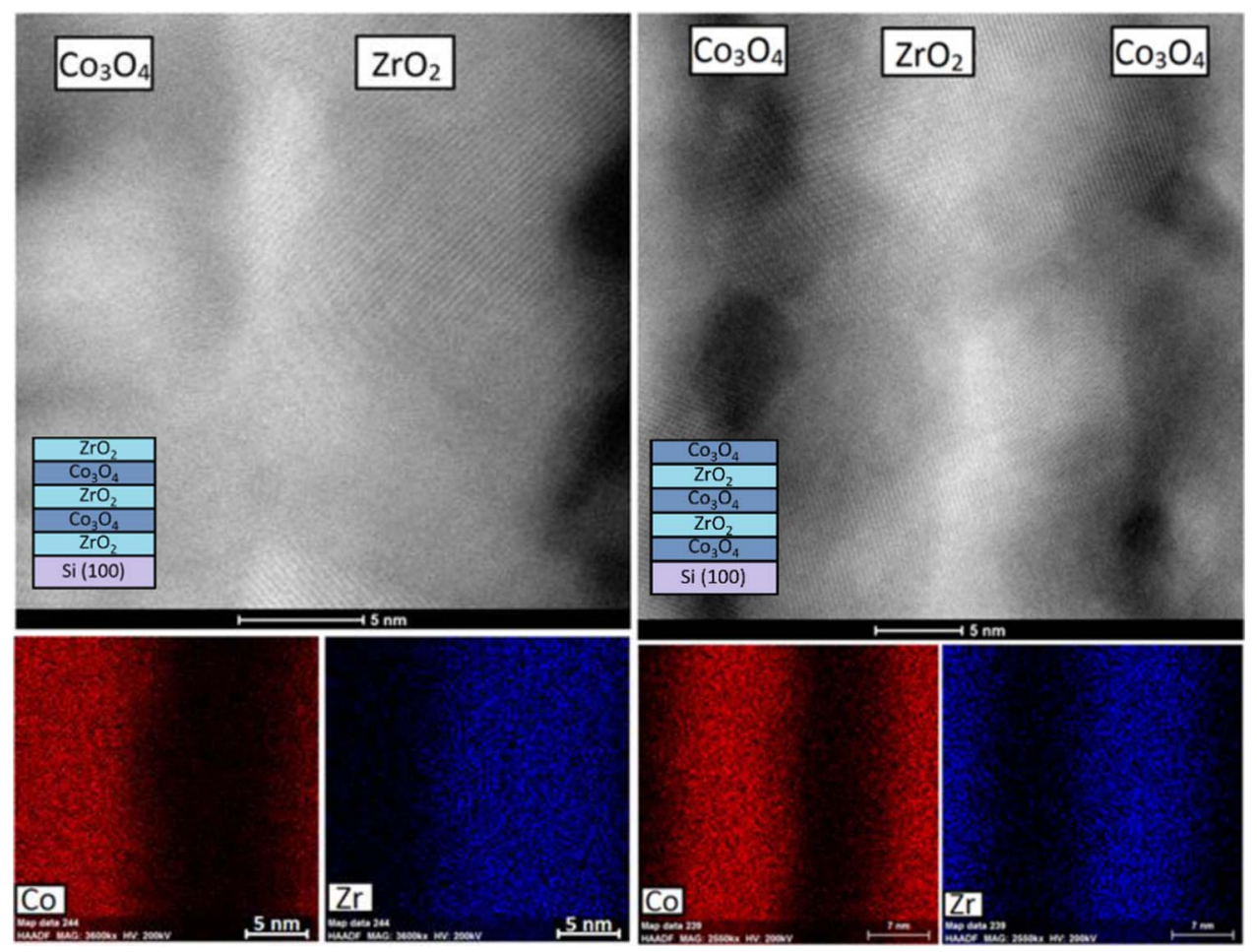

Figure 5. Cross-sectional STEM image and EDX composition profiling taken from the lamellae that were made of the nanolaminates in the as-deposited state. $2 \times\left(\mathrm{ZrO}_{2}+\mathrm{Co}_{3} \mathrm{O}_{4}\right)+\mathrm{ZrO}_{2}$ nanolaminate on the left panels and $2 \times\left(\mathrm{Co}_{3} \mathrm{O}_{4}+\mathrm{ZrO}_{2}\right)+\mathrm{Co}_{3} \mathrm{O}_{4}$ on the right panels.

deposited do not consist of stable crystallographic phases characteristic of perfectly stoichiometric zirconium dioxide. It is likely that the deposited oxides have not been fully oxidized due to the low deposition temperature. Thus, noticeable magnetization is likely caused by a significant contribution from nanocrystalline cubic tetragonal $\mathrm{ZrO}_{2}$ phase.

From the resistive switching loops (Fig. 8) one can see that both samples show bipolar behavior, but with opposite sign. In the sample $\mathrm{Si} / \mathrm{TiN} / 2 \times\left(\mathrm{Co}_{3} \mathrm{O}_{4}+\mathrm{ZrO}_{2}\right)+\mathrm{Co}_{3} \mathrm{O}_{4} / \mathrm{Pt}$ (Fig. 8, lower panel) the transition from low to high resistance states (SET) ${ }^{69,70}$ occurs for negative voltages between -1.5 and $-2.5 \mathrm{~V}$, whereas the transition from high to low resistance state (RESET) occurs for positive voltages in the range of $2.0-3.5 \mathrm{~V}$. It can also be noticed that both transitions are very sharp and currents at the low resistance state are more than

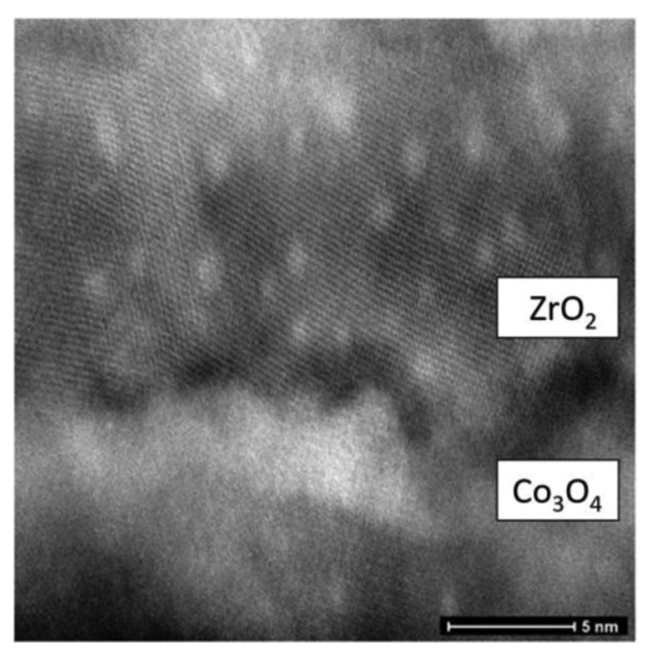

Figure 6. Cross-sectional STEM image taken of the $2 \times\left(\mathrm{ZrO}_{2}+\mathrm{Co}_{3} \mathrm{O}_{4}\right)+$ $\mathrm{ZrO}_{2}$ nanolaminate. one order of magnitude higher than at the OFF state. On the contrary, in the sample $\mathrm{Si} / \mathrm{TiN} / 2 \times\left(\mathrm{ZrO}_{2}+\mathrm{Co}_{3} \mathrm{O}_{4}\right)+\mathrm{ZrO}_{2} / \mathrm{Pt}$ (Fig. 8, upper panel) SET occurs at positive of about $6 \mathrm{~V}$, whereas RESET occurs at negative voltages in the range of $-6-(-8) \mathrm{V}$, and both transitions are very gradual. Moreover, it is evident that the loops are much narrower.

The opposite sign of the bipolar loops can be related to the different ordering of the multilayers. The conductive filaments in this kind of materials are typically formed due to the accumulation of oxygen vacancies, which cluster, so connecting top and bottom electrodes (set process). Oxygen vacancies are caused due to the migration of negative oxygen ions due to the electric field. RESET process is based on the opposite mechanism: oxygen anions are moved from the metal to the insulator and backfill the vacancies to annihilate the conductive

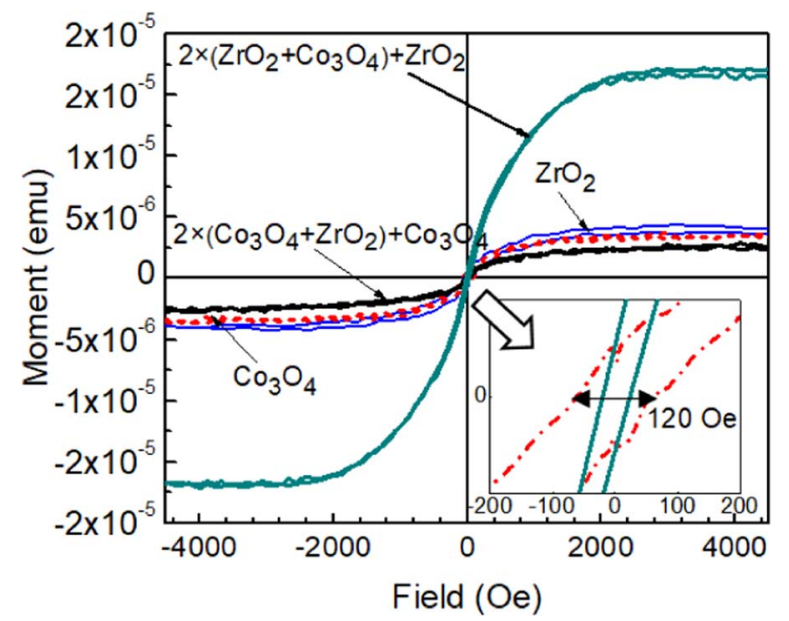

Figure 7. Magnetic moment vs. external magnetic field $(\boldsymbol{M}-\boldsymbol{H})$ curves for the as-deposited $\mathrm{ZrO}_{2}-\mathrm{Co}_{3} \mathrm{O}_{4}$ nanolaminates and $\mathrm{ZrO}_{2}$ and $\mathrm{Co}_{3} \mathrm{O}_{4}$ reference thin films measured at room temperature $(300 \mathrm{~K})$. 

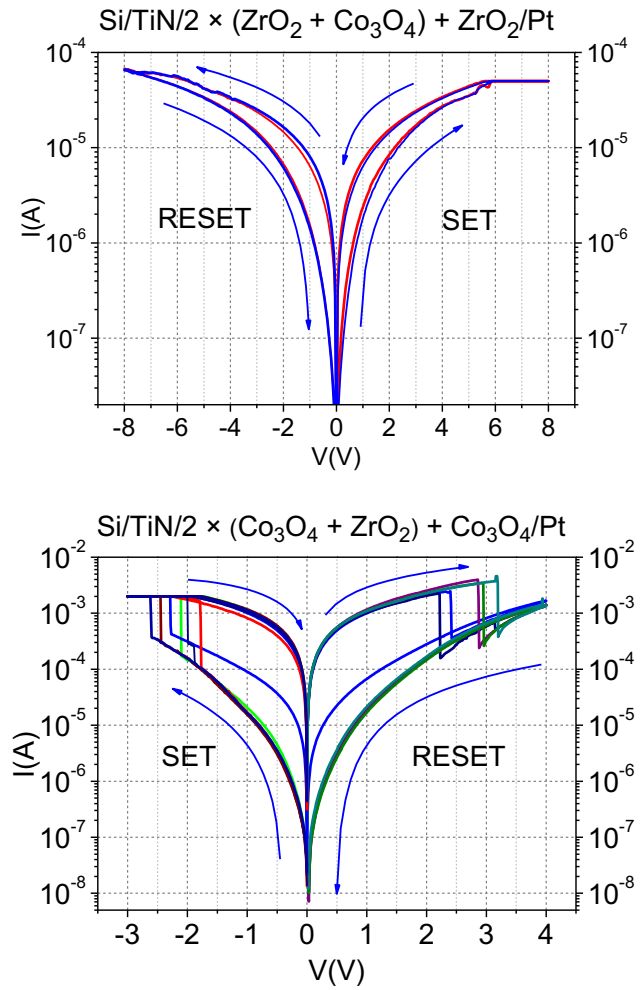

Figure 8. Current-voltage curves measured from the $\mathrm{Si} / \mathrm{TiN} / 2 \times\left(\mathrm{ZrO}_{2}+\right.$ $\left.\mathrm{Co}_{3} \mathrm{O}_{4}\right)+\mathrm{ZrO}_{2} / \mathrm{Pt}$ (upper panel) and $\mathrm{Si} / \mathrm{TiN} / 2 \times\left(\mathrm{Co}_{3} \mathrm{O}_{4}+\mathrm{ZrO}_{2}\right)+\mathrm{Co}_{3} \mathrm{O}_{4} / \mathrm{Pt}$ (lower panel) MIM samples.

path. Therefore, the negative reset voltage indicates that oxygen atoms coming from the top electrode cause the conductive filament oxidation in the adjacent insulator, that is, in the upper dielectric region. That is the case of sample $\mathrm{Si} / \mathrm{TiN} / 2 \times\left(\mathrm{ZrO}_{2}+\mathrm{Co}_{3} \mathrm{O}_{4}\right)+\mathrm{ZrO}_{2} / \mathrm{Pt}$, where the upper film is $\mathrm{ZrO}_{2}$, which is in contact with the top Pt electrode. $\mathrm{Pt}$ is reputed to be highly active as an oxygen repository in bipolar switching devices (in contrast, TiN used to be very inactive). In a $\mathrm{Si} / \mathrm{TiN} / 2 \times$ $\left(\mathrm{Co}_{3} \mathrm{O}_{4}+\mathrm{ZrO}_{2}\right)+\mathrm{Co}_{3} \mathrm{O}_{4} / \mathrm{Pt}$ nanolaminate, where the $\mathrm{Co}_{3} \mathrm{O}_{4}$ layer is in contact with both of the electrodes, SET and RESET occurs for negative and positive voltages, respectively. Moreover, current loops are wider than for the $\mathrm{Si} / \mathrm{TiN} / 2 \times\left(\mathrm{ZrO}_{2}+\mathrm{Co}_{3} \mathrm{O}_{4}\right)+\mathrm{ZrO}_{2} / \mathrm{Pt}$ sample. Tentative explanation is that in these samples, the dominant mechanism is the migration of Co cations to the $\mathrm{ZrO}_{2}$ insulation layer, that is, resistive switching is caused by the electrochemical metallization of the $\mathrm{ZrO}_{2}$ layer.

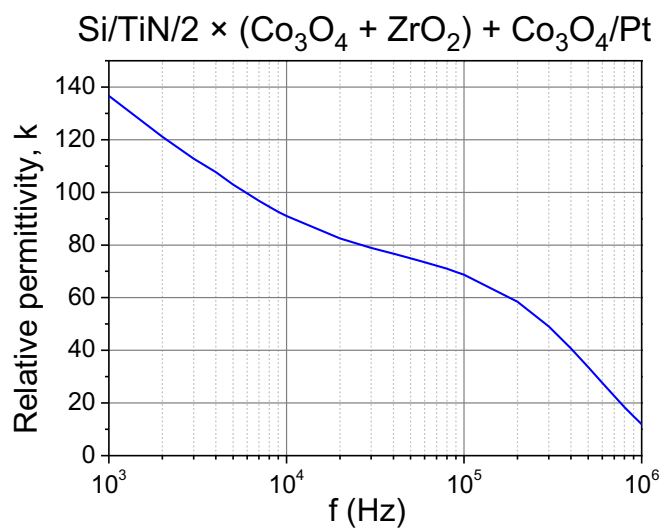

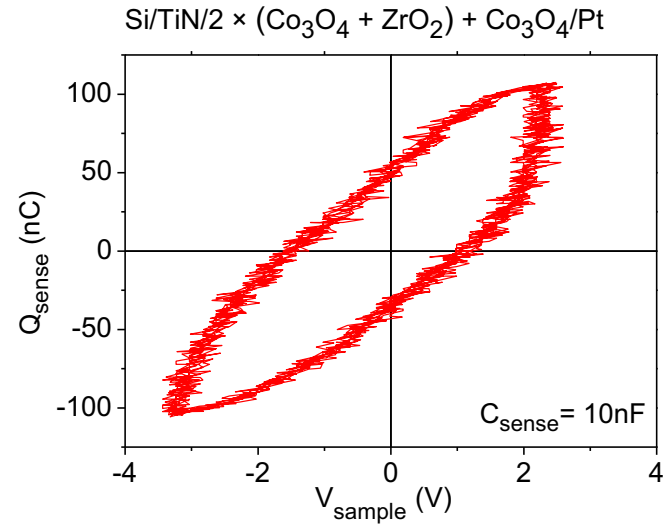

Figure 9. $\mathrm{P}-\mathrm{V}$ curves of the $\mathrm{Si} / \mathrm{TiN} / 2\left(\mathrm{Co}_{3} \mathrm{O}_{4}+\mathrm{ZrO}_{2}\right)+\mathrm{Co}_{3} \mathrm{O}_{4} / \mathrm{Pt}$ recorded during the Sawyer-Tower measurements. The value of $\mathrm{C}_{\text {sense }}$ was $10 \mathrm{nF}$.

The charge polarization - voltage $(\mathrm{P}-\mathrm{V})$ hysteresis loops measured during the Sawyer-Tower measurements for the Si/TiN/2 $\times\left(\mathrm{Co}_{3} \mathrm{O}_{4}+\right.$ $\left.\mathrm{ZrO}_{2}\right)+\mathrm{Co}_{3} \mathrm{O}_{4} / \mathrm{Pt}$ (Fig. 9) and $\mathrm{Si} / \mathrm{TiN} / 2 \times\left(\mathrm{ZrO}_{2}+\mathrm{Co}_{3} \mathrm{O}_{4}\right)+\mathrm{ZrO}_{2} / \mathrm{Pt}$ (not shown) samples were not promising. The charge polarization was about $55 \mathrm{nC}$ at $0 \mathrm{~V}$ for the $\mathrm{Si} / \mathrm{TiN} / 2 \times\left(\mathrm{Co}_{3} \mathrm{O}_{4}+\mathrm{ZrO}_{2}\right)+\mathrm{Co}_{3} \mathrm{O}_{4} / \mathrm{Pt}$ nanolaminate and $0.6 \mathrm{nC}$ at $0 \mathrm{~V}$ for the $\mathrm{Si} / \mathrm{TiN} / 2 \times\left(\mathrm{ZrO}_{2}+\mathrm{Co}_{3} \mathrm{O}_{4}\right)+$ $\mathrm{ZrO}_{2} / \mathrm{Pt}$ nanolaminate. The shape of those loops is typical to a lossy dielectric and therefore not characteristic to a ferroelectric material. ${ }^{71}$

In general, the films grown in the present study performed as moderately insulating dielectric metal oxides. The capacitance measurements revealed that the oxide layers in metal-oxide-nitride exhibited dielectric dispersion behavior rather common in high-permittivity oxide materials. The permittivity values measured in these laminates evidently exceeded 30-35 at measurement frequencies ranging from 1 to $10 \mathrm{kHz}$ (Fig. 10), which can be explained by considerable contribution of metastable crystalline $\mathrm{ZrO}_{2}$ phases in the films. However, in the laminate with structure of $2 \times\left(\mathrm{Co}_{3} \mathrm{O}_{4}+\mathrm{ZrO}_{2}\right)+\mathrm{Co}_{3} \mathrm{O}_{4}$ the apparent permittivity value at relatively low frequencies approached values as high as 100 , which is most likely due to high leakage in the films and concurrent interface or space charge polarization.

In the five-layer nanolaminates investigated in the present study, the dominance of metastable $\mathrm{ZrO}_{2}$ polymorphs (cubic/tetragonal) over the monoclinic phase appeared somewhat clearer compared to that observed earlier in $\mathrm{ZrO}_{2} / \mathrm{Co}_{3} \mathrm{O}_{4}$ double layers, ${ }^{59}$ decided on the basis of XRD results. Concurrently, the saturation magnetization tended to be higher, although differences in the magnetization hysteresis width occurred insignificant. Charge polarization in the capacitor structures did not differ essentially in nanolaminates and double layers. At the same time, nanolaminates in the present study tended to demonstrate somewhat wider window between high and low resistance states, as

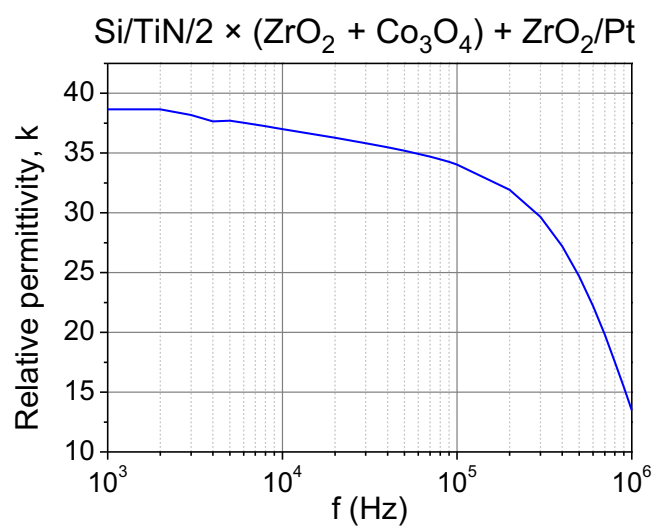

Figure 10. Permittivity dispersion in the nanolaminate films with structures denoted by labels. 
measured in the resistive switching regime. The high resistance state was thereby realized at lower current values, which may expected to be advantageous when aiming at lowered power consumption during the information reading process, if such materials were applied in memristor cells.

\section{Summary}

$\mathrm{ZrO}_{2}-\mathrm{Co}_{3} \mathrm{O}_{4}$ nanolaminates were grown by atomic layer deposition. The films consisting of distinct metal oxide layers were formed. The performance of the laminate films was dependent on the relative content of constituent oxide layers. The structure that consisted alternately of three $\mathrm{ZrO}_{2}$ and two $\mathrm{Co}_{3} \mathrm{O}_{4}$ layers showed higher magnetization compared to the structure that consisted alternately of three $\mathrm{Co}_{3} \mathrm{O}_{4}$ and two $\mathrm{ZrO}_{2}$ layers. All studied structures exhibited characteristics that are inherent to ferro- or ferrimagnetic materials like saturation magnetization and non-linear relationship between magnetic moment and external magnetic field. Electrical measurements revealed formation of significant polarization versus external field loops, probably markedly influenced by interfacial polarization and both samples showed bipolar behavior in resistive switching regime, although with an opposite sign.

\section{Acknowledgments}

The authors of the paper are thankful to Alma-Asta Kiisler for the technical assistance in sample preparation, to Jekaterina Kozlova for sharing her support and knowledge in connection with the lamellae creation process, to Peeter Ritslaid for his support in XRF studies and to Dr. Aarne Kasikov for depositing the electrodes and ellipsometric measurements. The study was partially supported by the European Regional Development Fund project "Emerging orders in quantum and nanomaterials" (TK134), Estonian Academy of Sciences (SLTFYPROF), Estonian Research Agency (IUT2-24, PRG4) and Spanish Ministry of Economy and Competitiveness (TEC201784321-C4-2-R) with support of Feder funds.

\section{ORCID}

Helina Seemen (D) https://orcid.org/0000-0002-4850-0851 Kristjan Kalam (D) https://orcid.org/0000-0001-5934-1860 Timo Sajavaara (1D https://orcid.org/0000-0003-2235-7441 Salvador Dueñas (D https://orcid.org/0000-0002-2328-1752 Helena Castán (1D https://orcid.org/0000-0002-3874-721X Raivo Stern (10) https://orcid.org/0000-0002-6724-9834 Kaupo Kukli (1) https://orcid.org/0000-0002-5821-0364 Aile Tamm (D) https://orcid.org/0000-0002-0547-0824

\section{References}

1. J. Riegel, H. Neumann, and H.-M. Wiedenmann, "Exhaust gas sensors for automotive emission control," Solid State Ion. 152-153, 783 (2002).

2. G. Lu, N. Miura, and N. Yamazoe, "High-temperature hydrogen sensor based on stabilized zirconia and a metal oxide electrode," Sens. Actuators B Chem., 35, 130 (1996).

3. P. D. L. Mercera, J. G. van Ommen, E. B. M. Doesburg, A. J. Burggraaf, and J. R. H. Ross, "Zirconia as a support for catalysts: influence of additives on the thermal stability of the porous texture of monoclinic zirconia," Appl. Catal., 71, 363 (1991).

4. J. Ftouni, A. Muñoz-Murillo, A. Goryachev, J. P. Hofmann, E. J. M. Hensen, L. Lu, C. J. Kiely, P. C. A. Bruijnincx, and B. M. Weckhuysen, " $\mathrm{ZrO}_{2}$ is preferred over $\mathrm{TiO}_{2}$ as support for the Ru-catalyzed hydrogenation of levulinic acid to $\gamma$-valerolactone," ACS Catal., 6, 5462 (2016).

5. D. Zhu and R. A. Miller, "Thermal conductivity and elastic modulus evolution of thermal barrier coatings under high heat flux conditions," J. Therm. Spray Tech., 9. 175 (2000)

6. U. Schulz and M. Schmücker, "Microstructure of $\mathrm{ZrO}_{2}$ thermal barrier coatings applied by EB-PVD," Mater. Sci. Eng.: A, 276, 1 (2000).

7. S. B. Ogale, R. D. Vispute, and R. R. Rao, "Pulsed excimer laser deposition $\mathrm{Y}_{1} \mathrm{Ba}_{2} \mathrm{Cu}_{3} \mathrm{O}_{7-\mathrm{x}}$ superconductor films on silicon with laser-deposited $\mathrm{Y}-\mathrm{ZrO}_{2}$ buffer layer," Appl. Phys. Lett., 57, 1805 (1990).
8. H. Schmidt, K. Hradil, W. Hösler, and W. Wersing, "Epitaxial $\mathrm{YBa}_{2} \mathrm{Cu}_{3} \mathrm{O}_{\mathrm{x}}$ thin films on sapphire using a Y-stabilized $\mathrm{ZrO}_{2}$ buffer layer," Appl. Phys. Lett., 59, 222 (1991).

9. H. J. Cho, Y. D. Kim, D. S. Park, E. Lee, C. H. Park, J. S. Jang, K. B. Lee, H. W. Kim, Y. J. Ki, I. K. Han, and Y. W. Song, "New TIT capacitor with $\mathrm{ZrO}_{2} / \mathrm{Al}_{2} \mathrm{O}_{3} / \mathrm{ZrO}_{2}$ dielectrics for $60 \mathrm{~nm}$ and below DRAMs," Solid-State Electron., 51, 1529 (2007).

10. K. Black, H. C. Aspinall, A. C. Jones, K. Przybylak, J. Bacsa, P. R. Chalker, S. Taylor, C. Z. Zhao, S. D. Elliott, and A. Zydor P. N. Heys, "Deposition of $\mathrm{ZrO}_{2}$ and $\mathrm{HfO}_{2}$ thin films by liquid injection MOCVD and ALD using ansa-metallocene zirconium and hafnium precursors," J. Mater. Chem., 18, 4561 (2008).

11. T. S. Kalkur and Y. C. Lu, "Electrical characteristics of $\mathrm{ZrO}_{2}$-based metal-insulatorsemiconductor structures on p-Si," Thin Solid Films, 207, 193 (1992).

12. S. Monaghan, K. Cherkaoui, É. O'Connor, V. Djara, P. K. Hurley, L. Oberbeck, E. Tois, L. Wilde, and S. Teichert, "TiN/ZrO $/ 2$ Ti/Al metal-insulator-metal capacitors with subnanometer CET using ALD-deposited $\mathrm{ZrO}_{2}$ for DRAM applications," IEEE Electron Device Lett., 30, 219 (2009).

13. D. Panda and T.-Y. Tseng, "Growth, dielectric properties, and memory device applications of $\mathrm{ZrO}_{2}$ thin films," Thin Solid Films, 531, 1 (2013).

14. C. Y. Lin, C.-Y. Wu, C.-Y. Wu, T.-C. Lee, F.-L. Yang, C. Hu, and T.-Y. Tseng, "Effect of top electrode material on resistive switching properties of $\mathrm{ZrO}_{2}$ film memory devices," IEEE Electron Device Lett., 28, 366 (2007).

15. Y. Li, S. Long, M. Zhang, Q. Liu, L. Shao, S. Zhang, Y. Wang, Q. Zuo, S. Liu, and M. Liu, "Resistive switching properties of $\mathrm{Au} / \mathrm{ZrO}_{2} / \mathrm{Ag}$ structure for low-voltage nonvolatile memory applications," IEEE Electron Device Lett., 31, 117 (2010).

16. Z. Wen, L. Zhu, W. Mei, L. Hu, Y. Li, L. Sun, H. Cai, and Z. Ye, "Rhombus-shaped $\mathrm{Co}_{3} \mathrm{O}_{4}$ nanorod arrays for high-performance gas sensor," Sens. Actuators B Chem., 186, 172 (2013).

17. S. Vetter, S. Haffer, T. Wagner, and M. Tiemann, "Nanostructured $\mathrm{Co}_{3} \mathrm{O}_{4}$ as a CO gas sensor: temperature-dependent behavior," Sens. Actuators B Chem., 206, 133 (2015).

18. S. Fujita, K. Suzuki, and T. Mori, "Preparation of high-performance $\mathrm{Co}_{3} \mathrm{O}_{4}$ catalyst for hydrocarbon combustion from Co-containing hydrogarnet," T. Catalysis Letters, 86, 139 (2003).

19. M. R. Mate, M. Shirai, and C. V. Rode, "Heterogeneous $\mathrm{Co}_{3} \mathrm{O}_{4}$ catalyst for selective oxidation of aqueous veratryl alcohol using molecular oxygen," Catal. Commun., 33, 66 (2013).

20. W. Y. Li, L. N. Xu, and Chen J, " $\mathrm{Co}_{3} \mathrm{O}_{4}$ nanomaterials in lithium-ion batteries and gas sensors," Adv. Funct. Mater., 15, 851 (2005).

21. Q. Liao, N. Li, S. Jin, G. Yang, and C. Wang, "All-solid-state symmetric supercapacitor based on $\mathrm{Co}_{3} \mathrm{O}_{4}$ nanoparticles on vertically aligned graphene," ACS Nano, 9 , 5310 (2015)

22. M. Moulapanah-Konaroi, M. Aliahmad, and H. Saravani, "Fabrication of superhydrophobic surface by $\mathrm{Co}_{3} \mathrm{O}_{4}$ nanoparticles," Indian J. Phys., 87, 211 (2013).

23. Z. Guo and W. Liu, "Superhydrophobic spiral $\mathrm{Co}_{3} \mathrm{O}_{4}$ nanorod arrays," Appl. Phys. Lett., 90, 193108 (2007).

24. J. Chen, X. Wu, and A. Selloni, "Electronic structure and bonding properties of cobalt oxide in the spinel structure," Phys. Rev. B, 83, 245204 (2011).

25. W. Hu, L. Zou, X. Lin, C. Gao, Y. Guo, and D. Bao, "Unipolar resistive switching effect and mechanism of solution-processed spinel $\mathrm{Co}_{3} \mathrm{O}_{4}$ thin films," Mater. Des., 103, 230 (2016).

26. X. Gao, H. Guo, Y. Xia, J. Yin, and Z. Liu, "Unipolar resistive switching characteristics in $\mathrm{Co}_{3} \mathrm{O}_{4}$ films," Thin Solid Films, 519, 450 (2010).

27. V. R. Shinde, S. B. Mahadik, T. P. Gujar, and C. D. Lokhande, "Supercapacitive cobalt oxide $\left(\mathrm{Co}_{3} \mathrm{O}_{4}\right)$ thin films by spray pyrolysis," Appl. Surf. Sci., 252, 7487 (2006).

28. G. Adamopoulos, S. Thomas, P. H. Wöbkenberg, D. D. C. Bradley, M. A. McLachlan, and T. D. Anthopoulos, "High-mobility low-voltage ZnO and Li-doped $\mathrm{ZnO}$ transistors based on $\mathrm{ZrO}_{2}$ high-k dielectric grown by spray pyrolysis in ambient air," Adv. Mater, 23, 1894 (2011).

29. S. Z. Abbas, A. A. Aboud, M. Irfan, and S. Alam, "Effect of substrate temperature on structure and optical properties of $\mathrm{Co}_{3} \mathrm{O}_{4}$ films prepared by spray pyrolysis technique," IOP Conf. Ser. Mater. Sci. Eng., 60, 012058 (2014).

30. T. S. Jeon, J. M. White, and D. L. Kwong, "Thermal stability of ultrathin $\mathrm{ZrO}_{2}$ films prepared by chemical vapor deposition on Si(100)," Appl. Phys. Lett., 78, 368 (2001).

31. C. M. Perkins, B. B. Triplett, P. C. McIntyre, K. C. Saraswat, S. Haukka, and M. Tuominen, "Electrical and materials properties of $\mathrm{ZrO}_{2}$ gate dielectrics grown by atomic layer chemical vapor deposition," Appl. Phys. Lett., 78, 2357 (2001).

32. N. Bahlawane, E. F. Rivera, K. Kohse-Höinghaus, A. Brechling, and U. Kleineberg, "Characterization and tests of planar $\mathrm{Co}_{3} \mathrm{O}_{4}$ model catalysts prepared by chemical vapor deposition," Appl. Catal. B Environ., 53, 245 (2004).

33. D. Barreca, C. Massignan, S. Daolio, M. Fabrizio, C. Piccirillo, L. Armelao, and E. Tondello, "Composition and microstructure of cobalt oxide thin films obtained from a novel cobalt(II) precursor by chemical vapor deposition," Chem. Mater, 13, 588 (2001).

34. Z.-W. Fu, Y. Wang, Y. Zhang, and Q.-Z. Qin, "Electrochemical reaction of nanocrystalline $\mathrm{Co}_{3} \mathrm{O}_{4}$ thin film with lithium," Solid State Ion., 170, 105 (2004).

35. J. Zhu and Z. G. Liu, "Structure and dielectric properties of ultra-thin $\mathrm{ZrO}_{2}$ films for high- $k$ gate dielectric application prepared by pulsed laser deposition," Appl. Phys. $A, 78,741$ (2004).

36. W.-C. Liu, D. Wu, A.-D. Li, H.-Q. Ling, Y.-F. Tang, and N.-B. Ming, "Annealing and doping effects on structure and optical properties of sol-gel derived $\mathrm{ZrO}_{2}$ thin films," Appl. Surf. Sci., 191, 181 (2002).

37. H. Tototzintle-Huitle, E. Prokhorov, A. Mendoza-Galván, J. E. Urbina, and J. González-Hernández, "Study of the formation of $\mathrm{Co}_{3} \mathrm{O}_{4}$ thin films using sol-gel method," J. Phys. Chem. Solids, 64, 975 (2003). 
38. K. Balachander, S. Arulkumaran, H. Ishikawa, K. Baskar, and T. Egawa, "Studies on electron beam evaporated $\mathrm{ZrO}_{2} / \mathrm{AlGaN} / \mathrm{GaN}$ metal-oxide-semiconductor highelectron-mobility transistors," Phys. Status Solidi A, 202, R16 (2005).

39. J. Wöllenstein, M. Burgmair, G. Plescher, T. Sulima, J. Hildenbrand, H. Böttner, and I. Eisele, "Cobalt oxide based gas sensors on silicon substrate for operation at low temperatures," Sens. Actuators B Chem., 93, 442 (2003).

40. M. Cassir, F. Goubin, C. Bernay, P. Vernoux, and D. Lincot, "Synthesis of $\mathrm{ZrO}_{2}$ thin films by atomic layer deposition: growth kinetics, structural and electrical properties," Appl. Surf. Sci., 193, 120 (2002).

41. M. Putkonen, J. Niinistö, K. Kukli, T. Sajavaara, M. Karppinen, H. Yamauchi, and L. Niinistö, " $\mathrm{ZrO}_{2}$ thin films grown on silicon substrates by atomic layer deposition with $\mathrm{Cp}_{2} \mathrm{Zr}\left(\mathrm{CH}_{3}\right)_{2}$ and water as precursors," Chem. Vap. Depos., 9, 207 (2003).

42. W.-H. Nam and S.-W. Rhee, "Atomic layer deposition of $\mathrm{ZrO}_{2}$ thin films using dichlorobis[bis-(trimethylsilyl)amido]zirconium and water," Chem. Vap. Depos., 10 201 (2004)

43. J. Niinistö, A. Rahtu, M. Putkonen, M. Ritala, M. Leskelä, and L. Niinistö, "In situ quadrupole mass spectrometry study of atomic-layer deposition of $\mathrm{ZrO}_{2}$ using $\mathrm{Cp}_{2} \mathrm{Zr}\left(\mathrm{CH}_{3}\right)_{2}$ and water," Langmuir, 21, 7321 (2005).

44. K. B. Klepper, O. Nilsen, and H. Fjellvåg, "Growth of thin films of $\mathrm{Co}_{3} \mathrm{O}_{4}$ by atomic layer deposition," Thin Solid Films, 515, 7772 (2007).

45. B. Han, J.-M. Park, K. H. Choi, W.-K. Lim, T. R. Mayangsari, W. Koh, and W.-J. Lee, "Atomic layer deposition of stoichiometric $\mathrm{Co}_{3} \mathrm{O}_{4}$ films using bis(1,4-di-iso-propyl1,4-diazabutadiene) cobalt," Thin Solid Films, 589, 718 (2015).

46. K. Kukli, M. Kemell, J. Köykkä, K. Mizohata, M. Vehkamäki, M. Ritala, and M. Leskelä, "Atomic layer deposition of zirconium dioxide from zirconium tetrachloride and ozone," Thin Solid Films, 589, 597 (2015)

47. W. F. A. Besling, E. Young, T. Conard, C. Zhao, R. Carter, W. Vandervorst, M. Caymax, S. De Gendt, M. Heyns, J. Maes, M. Tuominen, and S. Haukka, "Characterisation of ALCVD $\mathrm{Al}_{2} \mathrm{O}_{3}-\mathrm{ZrO}_{2}$ nanolaminates, link between electrical and structural properties," J. Non-Cryst. Solids, 303, 123 (2002).

48. J. Meyer, P. Görrn, F. Bertram, S. Hamwi, T. Winkler, H. -H. Johannes, T. Weimann, P. Hinze, T. Riedl, and W. Kowalsky, " $\mathrm{Al}_{2} \mathrm{O}_{3} / \mathrm{ZrO}_{2}$ nanolaminates as ultrahigh gasdiffusion barriers-a strategy for reliable encapsulation of organic electronics," Adv Mater, 21, 1845 (2009)

49. Z. Tang, X. Zhu, H. Xu, Y. Xia, J. Yin, Z. Liu, A. Li, and F. Yan, "Impact of the interfaces in the charge trap layer on the storage characteristics of $\mathrm{ZrO}_{2} / \mathrm{Al}_{2} \mathrm{O}_{3}$ nanolaminate-based charge trap flash memory cells," Mater. Lett., 92, 21 (2013).

50. G. Balakrishnan, A. Wasy, H. S. Ho, P. Sudhakara, S. I. Bae, and J. I. Song, "Study of $\mathrm{Al}_{2} \mathrm{O}_{3} / \mathrm{ZrO}_{2}(5 \mathrm{~nm} / 20 \mathrm{~nm})$ nanolaminate composite," Compos. Res., 26, 60 (2013).

51. L. Zhong, F. Chen, S. A. Campbell, and W. L. Gladfelter, "Nanolaminates of zirconia and silica using atomic layer deposition," Chem. Mater., 16, 1098 (2004)

52. K. Kukli, J. Ihanus, M. Ritala, and M. Leskelä, "Properties of $\mathrm{Ta}_{2} \mathrm{O}_{5}$-based dielectric nanolaminates deposited by atomic layer epitaxy," J. Electrochem. Soc., 144, 300 (1997).

53. H. Zhang and R. Solanki, "Atomic layer deposition of high dielectric constant nanolaminates," J. Electrochem. Soc., 148, F63 (2001).
54. H. Kim, P. C. McIntyre, and K. C. Saraswat, "Microstructural evolution of $\mathrm{ZrO}_{2}-\mathrm{HfO}_{2}$ nanolaminate structures grown by atomic layer deposition," J. Mater. Res., 19, 643 (2004).

55. A. Tamm, M. Heikkilä, M. Kemell, J. Kozlova, K. Kukli, V. Sammelselg, M. Ritala, and M. Leskelä, "Atomic layer deposition and characterization of zirconium oxideerbium oxide nanolaminates," Thin Solid Films, 519, 666 (2010).

56. I. Jõgi, A. Tamm, K. Kukli, M. Kemell, J. Lu, T. Sajavaara, M. Ritala, and M. Leskelä, "Investigation of $\mathrm{ZrO}_{2}-\mathrm{Gd}_{2} \mathrm{O}_{3}$ based high- $k$ materials as capacitor dielectrics," $J$. Electrochem. Soc., 157, G202 (2010).

57. C. N. Ginestra, R. Sreenivasan, A. Karthikeyan, S. Ramanathan, and P. C. McIntyre, "Atomic layer deposition of $\mathrm{Y}_{2} \mathrm{O}_{3} / \mathrm{ZrO}_{2}$ nanolaminates a route to ultrathin solid-state electrolyte membranes," Electrochem. Solid-State Lett., 10, B161 (2007).

58. P. Wiecinska, L. Skrzos, and N. Prokurat, "New route for processing of multilaye $\mathrm{Al}_{2} \mathrm{O}_{3}-\mathrm{Co}_{3} \mathrm{O}_{4}$ materials through gelcasting," J. Eur. Ceram. Soc., 37, 1627 (2017).

59. K. Kalam, H. Seemen, M. Mikkor, T. Jõgiaas, P. Ritslaid, A. Tamm, K. Kukli, A. Kasikov, J. Link, R. Stern, S. Dueñas, H. Castán, and H. García, Electrical and magnetic properties of atomic layer deposited cobalt oxide and zirconium oxide nanolaminates (submitted to Thin Solid Films).

60. T. Arroval, L. Aarik, R. Rammula, V. Kruusla, and J. Aarik, "Effect of substrateenhanced and inhibited growth on atomic layer deposition and properties of aluminium-titanium oxide films," Thin Solid Films, 600, 120 (2016)

61. V. Pore, M. Dimri, H. Khanduri, R. Stern, J. Lu, L. Hultman, K. Kukli, M. Ritala, and M. Leskelä, "Atomic layer deposition of ferromagnetic cobalt doped titanium oxide thin films," Thin Solid Films, 519, 3318 (2011).

62. R. Ramesh and N. A. Spaldin, "Multiferroics: progress and prospects in thin films," Nature Materials, 6, 22 (2007).

63. K. B. Klepper, O. Nilsen, and H. Fjellvåg, "Growth of thin films of $\mathrm{Co}_{3} \mathrm{O}_{4}$ by atomic layer deposition," Thin Solid Films, 515, 7772 (2007).

64. K. Kukli, J. Lu, J. Link, M. Kemell, E. Puukilainen, M. Heikkilä, R. Hoxha, L. Hultman A.Tamm, R. Stern, M. Ritala, and M. Leskelä, "Holmium and titanium oxide nanolaminates by atomic layer deposition," Thin Solid Films, 565, 165 (2014).

65. F. Máca, J. Kudrnovský, V. Drchal, and G. Bouzerar, "Magnetism without magnetic impurities in $\mathrm{ZrO}_{2}$ oxide," Applied Physics Letters, 92, 212503 (2008).

66. S. Ning, P. Zhan, Q. Xie, Z. Li, and Z. Zhang, "Room-temperature ferromagnetism in un-doped $\mathrm{ZrO}_{2}$ thin films," J. Phys. Appl. Phys., 46, 445004 (2013).

67. M. A. Rahman, S. Rout, J. P. Thomas, D. McGillivray, and K. T. Leung, "Defect-rich dopant-free $\mathrm{ZrO}_{2}$ nanostructures with superior dilute ferromagnetic semiconductor properties," J. Am. Chem. Soc., 138, 11896 (2016).

68. M. C. Dimri, H. Khanduri, H. Kooskora, M. Kodu, R. Jaaniso, I. Heinmaa, A. Mere, J. Krustok, and R. Stern, "Room-temperature ferromagnetism in Ca and Mg stabilized cubic zirconia bulk samples and thin films prepared by pulsed laser deposition," $J$. Phys. Appl. Phys., 45, 475003 (2012).

69. D. Ielmini, "Resistive switching memories based on metal oxides: mechanisms, reliability and scaling," Semicond. Sci. and Technol., 31, 063002 (2016).

70. F. Pan, C. Chen, Z.-S. Wang, Y.-C. Yang, J. Yang, and F. Zeng, "Nonvolatile resistive switching memories-characteristics, mechanisms and challenges," Prog. Nat. Sci. Mater. Int., 20, 1 (2010).

71. J. F. Scott, "Ferroelectrics go bananas," J. Phys. Condens. Matter, 20, 021001 (2008). 